\title{
MICRONUCLEI AND NUCLEAR ABNORMALITIES IN ERYTHROCYTES FROM BARBEL BARBUS PELOPONNESIUS REVEALING GENOTOXIC POLLUTION OF THE RIVER BREGALNICA
}

\author{
Lozenka Ivanova ${ }^{1}$, Florina Popovska-Percinic ${ }^{2}$, Valentina Slavevska-Stamenkovic ${ }^{1}$, \\ Maja Jordanova ${ }^{1}$, Katerina Rebok ${ }^{1}$
}

${ }^{1}$ Institute of Biology, Faculty of Natural Sciences and Mathematics, Ss Cyril and Methodius University, Arhimedova str., n. 3, 1000 Skopje, R. Macedonia ${ }^{2}$ Faculty of Veterinary Medicine, Ss Cyril and Methodius University, Lazar Pop Trajkov 5-7, 1000 Skopje, R. Macedonia

Received 25 November 2015; Received in revised form 20 January 2016; Accepted 25 March 2016

\begin{abstract}
The strong negative anthropogenic pressure on the River Bregalnica resulted in the increase of pollution in the river ecosystem. The aim of this study was to evaluate if aquatic pollutants generate genotoxic effects in barbel (Barbus peloponnesius). Thirty individuals were collected from three localities along the river: one control site and two locations in the middle and lower course of the river with the presence of different pollution sources. Blood smears were stained with May-Grünwald/Giemsa method and the frequency of micronuclei, vacuolated nuclei, binuclei, blebbed nuclei and notched nuclei expressed in per mill was recorded. In fish collected from the control site, the investigated erythrocyte nuclear abnormalities revealed lowest values compared to polluted sites. In general, significantly higher values for erythrocyte deformations, including micronuclei, were noted in the middle and lower part of the river. Significantly higher values of vacuolated and blebbed nuclei were detected in fish from the middle course of the river, while at the lower course the frequencies of occurrence of micronuclei and notched nuclei were significant compared with control site. The middle course of the River Bregalnica has more diverse pollutants compared to the lower course, and consequently the highest frequency of all nuclear deformations was found in barbel from the middle course of the river. Obtained results suggest that pollutants draining into the Bregalnica river ecosystem display a genotoxic effect on the local barbel population.
\end{abstract}

Key words: river barbel, genotoxic effects, erythrocyte abnormalities, pollution

\section{INTRODUCTION}

Since the first description of the morphological nuclear alterations in fish erythrocytes (1), a number of papers published during the past decades reported the appearance of erythrocyte nuclear abnormalities in fish $(2,3)$. These modifications of the shape and dimension of the nucleus lead to genetic instability, cell dysfunction and/or cell death $(4,5)$. Although these changes can occur naturally, it is proposed that pollutants can cause a manifold increase in

Corresponding author: Assist. Prof. Katerina Rebok, PhD

E-mail address: katerinarebok@yahoo.com

Present address: Institute of Biology, Faculty of Natural Sciences and

Mathematics, Ss Cyril and Methodius University, Arhimedova str. 3,

1000 Skopje, R. Macedonia

Phone: ++38923249 624; Fax: ++ 38923228141

Copyright: (C) 2016 Ivanova L. This is an open-access article published under the terms of the Creative Commons Attribution License which permits unrestricted use, distribution, and reproduction in any medium, provided the original author and source are credited.

Competing Interests: The authors have declared that no competing interests exist.

Available Online First: 6 April 2016

Published on: 15 October 2016

http://dx.doi.org/10.1515/macvetrev-2016-0080 incidence of nuclear anomalies. One of the methods of studying genotoxic effects of different mutagens on the living organisms is the detection of frequency of micronuclei (MN) which is often used in studies of teleost fish (6). Other most commonly noted nuclear abnormalities caused by genotoxins are vacuolated nucleus (VN), binucleus (BiN), notched nucleus (NotchN) and blebbed nucleus (BlebN) $(2,3)$.

Fish are shown to be excellent subjects for detection of potential mutagenic and/or carcinogenic effects of contaminants in water, because they can metabolize, concentrate and store different pollutants. This makes them a good model organism for experimenting with potential toxins that can influence humans, as well (7). In general, changes in fish will reflect the changes in the environment because of their sensitivity to low concentrations of genotoxins (8). In addition, as top predators, fish will accumulate even higher amounts of genotoxins when feeding on other organisms that have consumed the pollutant, thereby being an indicator of the shape of whole ecosystem (9). 
The river Bregalnica is situated in the eastern part of the Republic of Macedonia and represents the main water resource for all water-related activities (from irrigation to drinking water supply) in that region. Recent studies have revealed intensive negative anthropogenic pressure on the river, resulting in high water pollution $(10,11)$. Uncontrolled discharge of polluted waters into the river, directly or indirectly, threatens the ecosystem health. Examination of the exposed wildlife is necessary for the early detection of environmental damage and prediction about the potential human health risks.

Considering the increasing pollution trend of the river Bregalnica, especially in its middle and lower stretches, the aim of this study was to examine whether pollutants that are released in this river can generate genotoxic changes such as micronuclei and erythrocyte nuclear abnormalities in local barbel (Barbus peloponnesius, Valenciennes, 1842) population.

\section{MATERIAL AND METHODS}

Fish were collected from three localities along the Bregalnica River (Figure 1), during the period from October 2007 to September 2008. The locations were selected based on the presence of different pollution sources determined in previous studies on the river Bregalnica $(11,12,13$,$) . For a referent - control$ site (Site R), a locality near the town of Berovo was

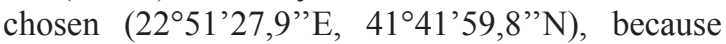
of an absence of urban, industrial and agricultural influences. The second locality (Site A) was near the village of Teranci in the middle course of the River Bregalnica $\left(22^{\circ} 20^{\prime} 58,5^{\prime \prime} \mathrm{E}, 41^{\circ} 51^{\prime} 45,4^{\prime \prime} \mathrm{N}\right)$. Site A has an influx of pollutants from agricultural activities, untreated communal wastewaters from the town of Kočani, and metal pollution from the nearby active zink and lead mine (Zletovo) via its tributary - the River Zletovska (13). In this locality, toxic substances enter the River Bregalnica directly through surface runoffs and indirectly through the River Zletovska. The third chosen locality (Site B) was near the town of Śtip $\left(22^{\circ} 10^{\prime} 27,0^{\prime \prime} E\right.$, $\left.41^{\circ} 43^{\prime} 55,0^{\prime \prime} \mathrm{N}\right)$, where contamination by untreated communal and chemically burdened wastewater from the textile industry was noted (12).

From each of localities, thirty barbel were collected with electro-fishing, covering a distance of nearly $1000 \mathrm{~m}$ downstream from the chosen points. Blood samples were taken from the caudal vein with heparinized $2.5 \mathrm{ml}$ sterile plastic syringes and needles from $0.45 \mathrm{~mm} \times 16 \mathrm{~mm}(27 \mathrm{G} \times 5 / 8$ inches $)$ to $0.8 \mathrm{~mm} \times 40 \mathrm{~mm}(21 \mathrm{G} \times 1.5$ inches $)$. Promptly after the collection, blood smears were made $(5$ slides per fish), air-dried and fixed 10 minutes in

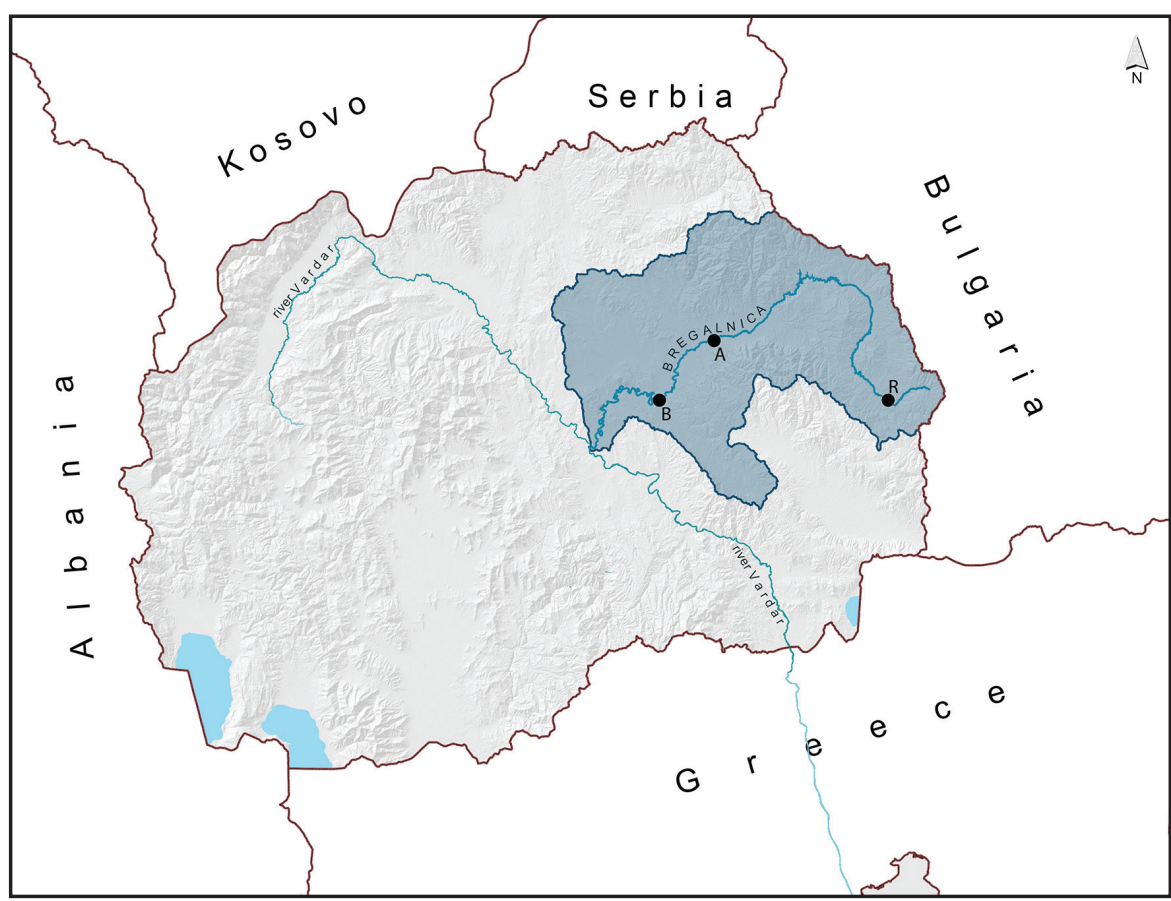

Figure 1. Map of Republic of Macedonia. The studied region in Eastern Macedonia is indicated. Letters correspond to the sample sites along the course of Bregalnica River: R - Control Site; A - Site A; B - Site B 
Erythrocytes nuclear abnormalities from barbel Barbus peloponnesius revealing river genotoxic pollution

methanol. The blood smears were afterward stained with May-Grünwald/Giemsa (MGG) method, modified according to Strunjak-Perovic et al. (14). On each slide, areas with uniform spread in monolayer without overlapping cells were targeted. From each slide 20 fields were analyzed (total - 100 fields per fish) at a magnification of $1000 x$, chosen by systematic random sampling method. Total number of analysed erythrocytes per fish varied from 8000-10000, depending on the density of cells distribution on the smear. Analyses consisted of detection and count of barbel's erythrocyte $\mathrm{MN}$, $\mathrm{VN}, \mathrm{BiN}$, NotchN and BlebN classified according to Carrasco et al. (1). Frequency of each nuclear anomaly was calculated relative to the total count of erythrocytes for each fish. All results were presented in per mill.

The obtained results are presented as mean values accompanied with coefficient of variation $(\mathrm{CV}=\mathrm{SD} /$ mean $)$. Software STATISTICA 7.0 for Windows was used for the statistical analysis. Oneway ANOVA, followed by post-hoc Newman-Keuls test were used for testing the effect of locality on the measuring parameters. Results were considered significant for probabilities greater than 95\% $(\mathrm{p}<0.05)$.

\section{RESULTS}

The frequency of MN (Table 1, Fig. 2a) showed lowest value in the control site (Site R), compared to the other two sites, while this parameter was significantly greater in Site B in comparison with the Sites R and A (Fig. 3a).

Values with different lowercase superscript letters in the same column represent significant differences $(p<0.05)$ between sampling sites, according to the ANOVA followed by post-hoc Newman-Keuls test.
The highest and significant frequency values for the VN and BlebN were recorded in Site A (Table 1, Fig. $2 b$ and $2 d$ ), compared to the other two sites (Fig. 3b; 3d). Concerning the BlebN, almost equal frequencies were recorded in Sites $\mathrm{R}$ and $\mathrm{B}$. On the other hand, the frequency of NotchN (Fig. 2e) revealed significantly higher values in fish collected in Site B (Table 1), compared to the other two locations (Fig. 3e).

The only parameter that did not show significant difference between investigated localities was BiN (Fig. 2c, Fig. 3c), in spite of the three-fold increased frequency of fluctuation in Site A $(0.93 \%)$ and six-fold increase in Site B (2.12\%o), compared to the control Site R (0.33\%o) (Table 1$)$.

The analysis of all nuclear abnormalities (TotalN) showed the lowest value in Site $\mathrm{R}$ and the highest value in Site A, which was significant compared to values in Sites R and B. (Fig. 3f).

In general, the Coefficient of Variation showed extremely high variability for all examined parameters. Minimal biological variation was noticed for $\mathrm{MN}$ in Site A $(0,40)$ and maximal for $\mathrm{BiN}$ in Site B $(2,01)$ (Table 1).

\section{DISCUSSION}

River Bregalnica has been intensively monitored in the past decade, and some researches revealed high water pollution, especially in Site A, where a complex mixture of pollutants derived from household wastewater, heavy metals from the nearby Zletovo mine and pesticides and fertilizers from agricultural activities admixes $(12,15)$. The results of this study showed the highest TotalN and a two- and three-fold higher $\mathrm{VN}$ and BlebN frequencies in fish from Site A, probably caused by the mixture of pollutants. Namely, literature data showed that synergistic effect of pollutants is more deleterious than their isolated influence (16).

Table 1. Frequency of barbel micronuclei* $(\mathrm{MN})$, vacuolated nuclei (VN), binuclei (BiN), blebbed nuclei (BlebN) and notched nuclei (NotchN), expressed as permiles from the Site R, Site A and Site B

\begin{tabular}{|c|c|c|c|c|c|c|}
\hline & MN (\%o) & VN (\%o) & $\mathrm{BiN}(\% 0)$ & BlebN (\%o) & NotchN (\%o) & TotalN (\%o) \\
\hline \multicolumn{7}{|c|}{ Locality } \\
\hline Site $\mathbf{R}$ & $7,27(0,91)^{\mathrm{a}}$ & $9,70(0,62)^{\mathrm{a}}$ & $0,33(0,71)$ & $28,47(0,91)^{\mathrm{a}}$ & $1,35(0,44)^{\mathrm{a}}$ & $4,71(0,23)^{\mathrm{a}}$ \\
\hline Site A & $12,09(0,40)^{\mathrm{a}}$ & $31,75(0,44)^{b}$ & $0,93(1,37)$ & $62,75(0,72)^{\mathrm{b}}$ & $1,80(0,38)^{\mathrm{ab}}$ & $11,01(0,17)^{\mathrm{b}}$ \\
\hline Site B & $22,31(0,47)^{\mathrm{b}}$ & $16,85(0,48)^{\mathrm{a}}$ & $2,12(2,01)$ & $28,18(0,59)^{\mathrm{ab}}$ & $2,62(0,53)^{b}$ & $9,05(0,21)^{\mathrm{a}}$ \\
\hline
\end{tabular}

"Values are expressed as mean (coefficient of variation) 

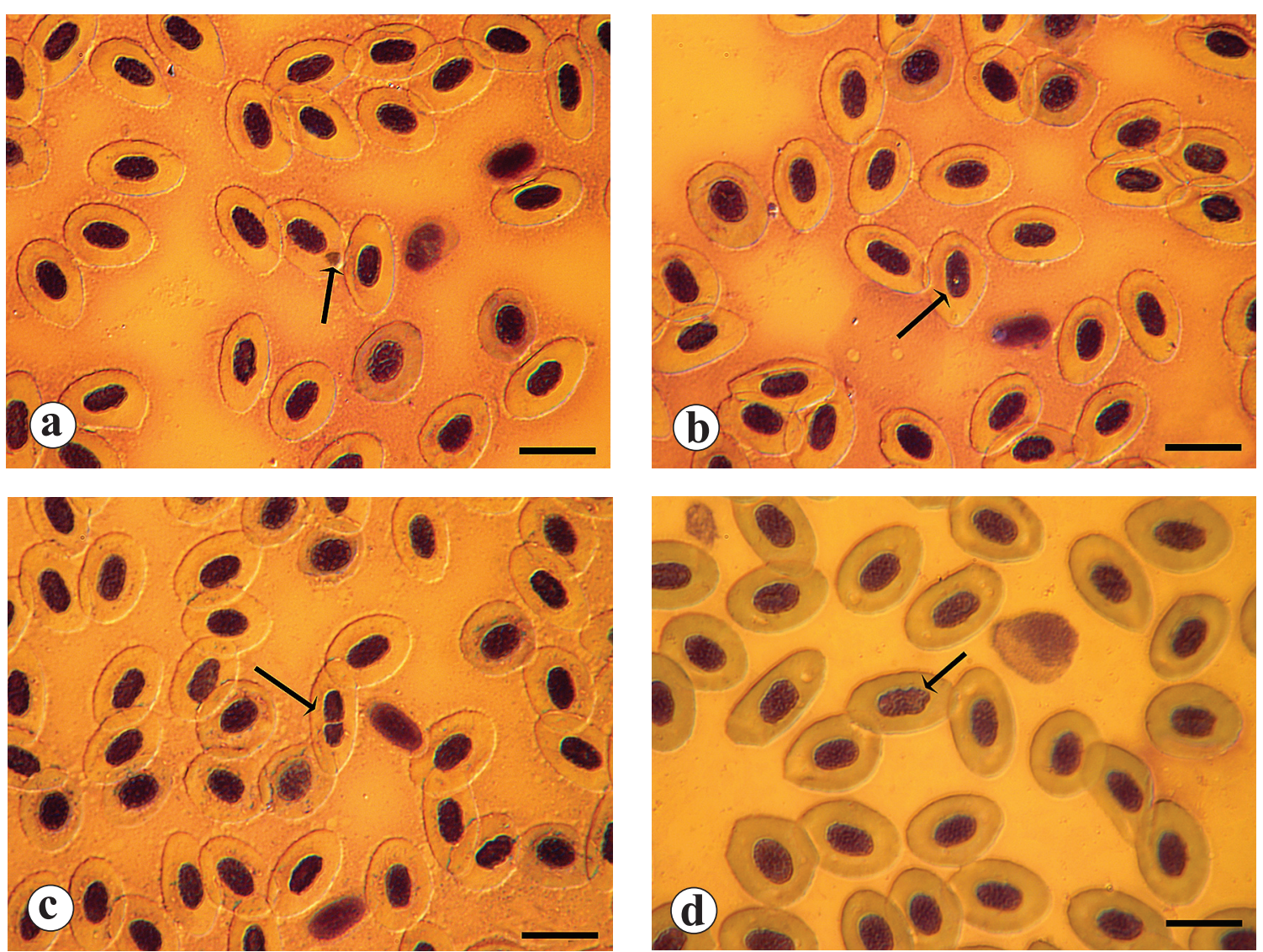

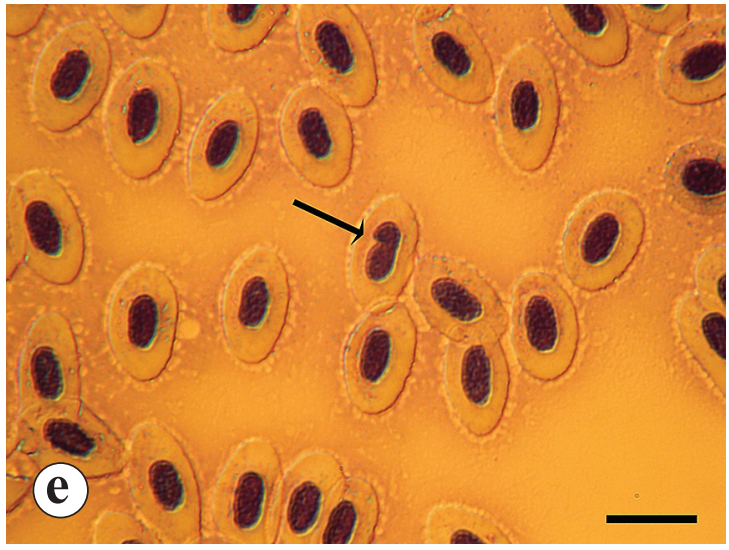

Compared to the Site R, although MN was not the highest at this point (Site A), we have recorded extremely higher frequencies of $\mathrm{VN}$ and BlebN, which are considered as predecessor for MN $(17,18)$. Although the etiology of $\mathrm{VN}$ is not known, some authors suggest that it is a result of aneuploidy leading to micronuclei (18). Verstraeten et al. (19) described donut-shaped nuclei induced by genotoxins formed due to de-condensation of chromatin in late mitosis. In their study (19), the described donut-shaped nuclei exhibited defects in karyokinesis, aneuploidy and often multinucleation. These defects are in accordance with the proposed 162 association of $\mathrm{VN}$, as aneuploidies that lead to $\mathrm{MN}$ by Anbumani and Mohankumar (18). Although there is no clear support yet, we presume that both $\mathrm{VN}$ and the donut-shaped nuclei might have similar mechanism of formation. If we presume that $\mathrm{VN}$ is analogous to the donut-shaped nuclei described by Verstraeten et al. (19), the results from our study, i.e. the high frequency of $\mathrm{VN}$ would lead to a conclusion of the presence of genotoxic substances into the water of Site A. However, this cannot be confirmed without further investigation.

BlebN whose frequencies are also extremely high in Site A is described as a mechanism of 
the cell to cope with excess chromatin that will become $\mathrm{MN}$ and then expelled from the cell as double minute - DM (17). Acute exposure causes significant damage that could induce apoptosis as opposed to chronic exposure that leaves a time to adapt and repair damage (18). It is possible that a prolonged exposure of barbel to pollution in this site leads to activation of certain mechanisms, e.g., a nuclear budding for removing excess chromatin, which could explain the extremely high frequency of BlebN.

Although we already noticed insignificantly higher MN frequencies in Site A compared with Site $\mathrm{R}$, we should take into account that $\mathrm{MN}$ circulation frequencies caused by different pollutants are dose, time and species dependent, reaching different peak-time, while after a prolonged exposure their frequencies decline $(20,21)$. Thus, in experiments
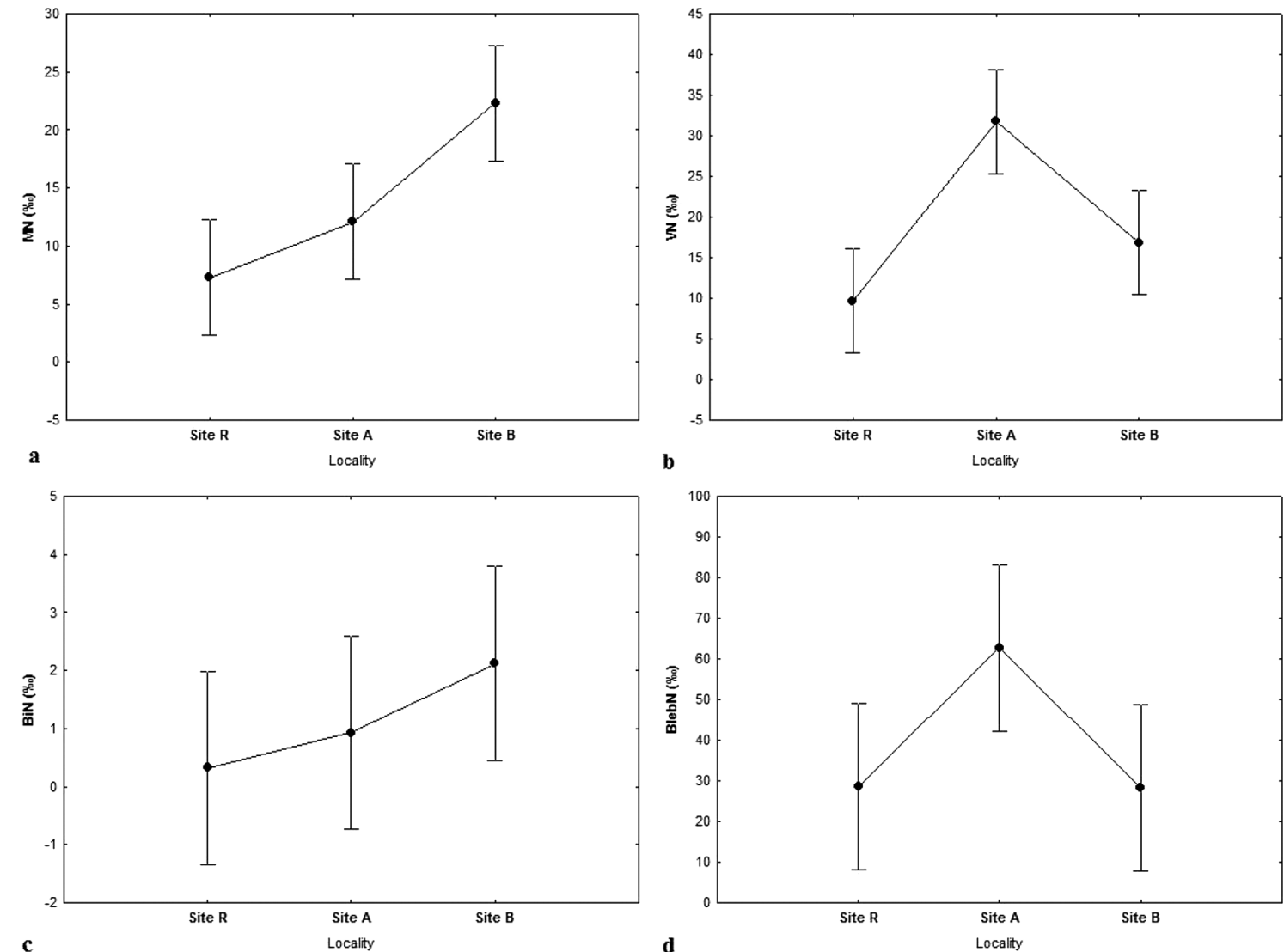

d
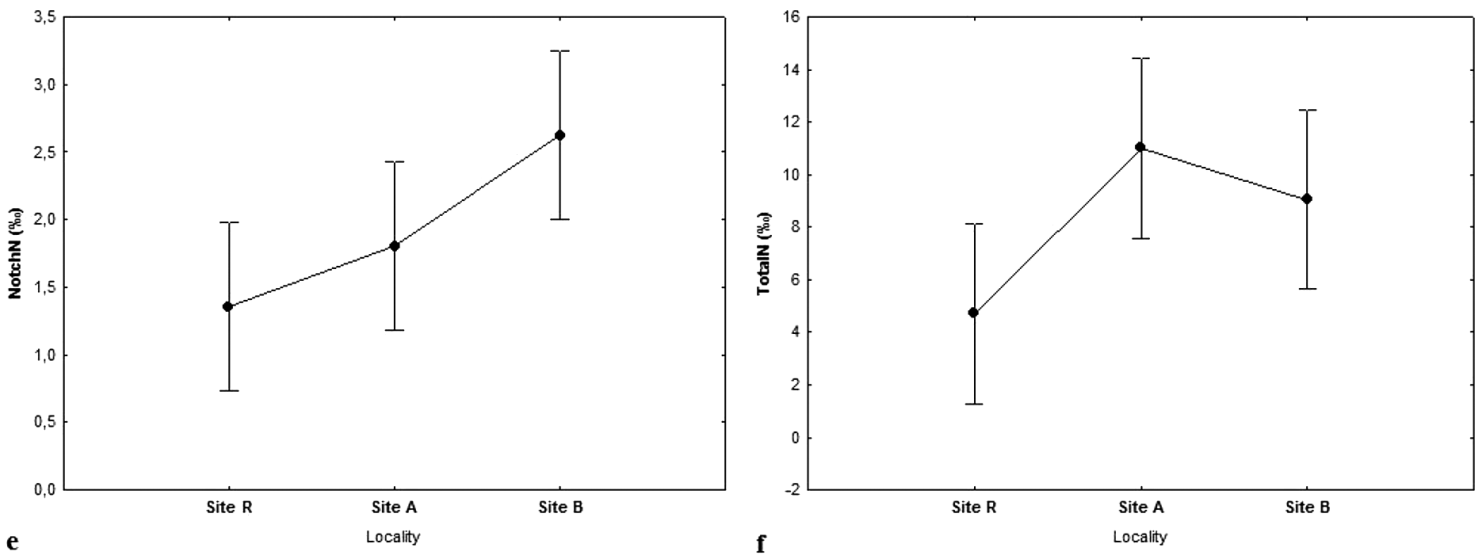

Figure 3. Changes in the frequency of the a) micronuclei - MN; b) vacuolated nuclei - VN; c) binuclei - BiN; d) blebbed nuclei-BlebN; e) notched nuclei - NotchN and f) total nuclear deformations - TotalN sampled from the selected sites. The data are expressed as mean, and vertical bars denote a 0.95 confidence interval 
with different concentrations of cadmium as genotoxin, the frequency of blood erythrocytes $\mathrm{MN}$ in Nile tilapia (Oreochromis niloticus) appears to have a peak at the fourth day and then decrease gradually, starting from the sixth day from the treatment (21). Experiments with higher concentrations of elemental or metallic mercury showed significant increase in $\mathrm{MN}$ frequencies in peripheral erythrocytes of Cyprinus carpio, which was higher after 31 days of exposure, followed by slight stabilization and gradual decrease (20).

Nepomuceno and Spanó (22) showed that exposure of Cyprinus carpio to different concentrations of pesticides induced $\mathrm{MN}$ formation in the blood erythrocytes in the first $24 \mathrm{~h}$, except for the highest concentration where highest $\mathrm{MN}$ frequencies were observed at $48 \mathrm{~h}$. According to these authors, this is a result of cell death at high concentration in the first $24 \mathrm{~h}$, which masked the appearance of MN. However, decrease of the $\mathrm{MN}$ frequencies after prolonged time might be a defensive mechanism/adaptation that stabilizes $\mathrm{MN}$ and nuclear abnormalities frequency due to removal of the damaged cells (20). Moreover, increased erythropoiesis can dilute or mask the number of $\mathrm{MN}$ and cell cycle and maturation time should be taken into account (23). In that line, insignificantly higher frequency of $\mathrm{MN}$ recorded in Site A compared with Site R, suggests that in this site genotoxic influence is prolonged. Prolonged exposure may allow decreasing of MN frequency by the removal of dying out or defective cells from circulation.

Highest frequency of $\mathrm{MN}, \mathrm{BiN}$ and NotchN were observed in Site B. The frequency of MN was significantly higher compared with other two sites, while the frequency of NotchN was significantly higher compared with the Site R. Although BiN frequency in fish from the Site $\mathrm{B}$ was twice bigger than frequency of this parameter in Site R, those differences were not significant probably due to big inter-individual variation observed for this nuclear abnormality. In Site B organic pollution and many detergent surfactants from the household wastewater, as well as textile industry wastewater are floweing into the river without pretreatment $(11,12)$. Urban wastewater is a complex mixture that is responsible for multiple effects in fish including genotoxic effects (24). Field based investigations with native fish populations (25) and in situ cage exposure (26) in river sectors after big cities, where the water quality deteriorates, revealed significantly increased $\mathrm{MN}$ frequencies. Only one specific stressor does not influence formation of $\mathrm{MN}$ and other nuclear abnormalities; it is rather multifactorial (14). In this vein, organic contaminants in the sediments have stronger genotoxic potency than heavy metals, while the presence of both heavy metals and organic 164 pollutants can decrease the overall genotoxic effects (27). Although textile industry wastewater could be a source of copper, chromium and nickel (28), metal toxic effects on barbel in the Site B is less expected than in the Site A. This is a result of the reduced bioavailability of metals which in this type of wastewater appear in form of complexes (28). Thus, we can assume that organic pollutants may have stronger genotoxic influence resulting with higher MN frequency in Site B.

\section{CONCLUSION}

Although the $\mathrm{MN}$ and other nuclear abnormalities revealed different pattern of variation along the river flow, the lowest values for all measured parameters were observed in the Site R. In general, significantly higher values for erythrocyte deformations, including $\mathrm{MN}$ noted in the middle and lower part of the river showed pollution burden of this water ecosystem. The results of this study suggest that all toxic materials that finally end into the river display genotoxic effect on aquatic organisms. Frequencies of $\mathrm{MN}$ and nuclear abnormalities may vary, depending on type of pollutants, their combination and time of exposure. The presence of $\mathrm{MN}$ and nuclear abnormalities should be taken as an early warning sign for the current status of this ecosystem concerning genotoxicity. The pollution pressure on the ecosystem by genotoxins should be controlled, in order to avoid reduction of reproductive potential and decrease in size of barbel population. This study provides a scientific basis for future investigations regarding the genotoxicity in the River Bregalnica ecosystem.

\section{REFERENCES}

1. Carrasco, K., Tilbury, K.L., Myers, M.S. (1990). Assessment of the piscine micronucleus test as an in situ biological indicator of chemical contaminant effects. Can J Fish Aquat Sci. 47, 2123-2136. http://dx.doi.org/10.1139/f90-237

2. Ayllón, F., Garcia-Vazquez, E. (2001). Micronuclei and other nuclear lesions as genotoxicity indicators in rainbow trout Oncorhynchus mykiss. Ecotoxicol Environ Saf. 49, 221-225.

http://dx.doi.org/10.1006/eesa.2001.2065 PMid: 11440474

3. Çavaş, T., Ergene-Gözükara, S. (2005). Induction of micronuclei and nuclear abnormalities in Oreochromis niloticus following exposure to petroleum refinery and chromium processing plant effluents. Aquat Toxicol. 74, 264-271.

http://dx.doi.org/10.1016/j.aquatox.2005.06.001 PMid:16023743 
4. Fenech, M. (2006). Cytokinesis-block micronucleus assay evolves into a "cytome" assay of chromosomal instability, mitotic dysfunction and cell death. Mutat Res. 600 (1-2): 58-66.

http://dx.doi.org/10.1016/j.mrfmmm.2006.05.028 PMid:16822529

5. Fulda, S., Gorman, A.M., Hori, O., Samali, A. (2010). Cellular Stress Responses: Cell Survival and Cell Death. Int J Cell Biol. 2010: 214074. http://dx.doi.org/10.1155/2010/214074

6. Al-Sabti, K., Metcalfe, C.D. (1995). Fish micronuclei for assessing genotoxicity in water. Mutat Res. 343, 121-135. http://dx.doi.org/10.1016/0165-1218(95)90078-0

7. Ali, F., El-Shehawi, A. M., Seehy, M. A. (2008). Micronucleus test in fish genome: A sensitive monitor for aquatic pollution. Afr J Biotechnol. 7 (5): 606-612.

8. Furnus, G.N.A, Caffetti, J.D., García, E.M., Benítez, M.F., Pastori, M.C., Fenocchio, A.S. (2014). Baseline micronuclei and nuclear abnormalities frequencies in native fishes from the Paraná River (Argentina). Braz J Biol. 74 (1): 217-221. http://dx.doi.org/10.1590/1519-6984.13712

9. van der Oost, R. (2003). Fish bioaccumulation and biomarkers in environmental risk assessment: a review. Environ Toxicol and Phar. 13, 57-149. http://dx.doi.org/10.1016/S1382-6689(02)00126-6

10. Balabanova, B., Stafilov, T., Šajn, R., Bačeva, K. (2013). Spatial distribution and characterization of some toxic metals and lithogenic elements in topsoil and subsoil from copper mine environs. Int J Environ Prot. 3 (9): 1-9.

11. Dimitrovska, O., Markoski, B., Apostolovska Toshevska, B., Milevski, I., Gorin, S. (2012). Surface water pollution of major rivers in the Republic of Macedonia. Procedia Environ Sci. 14, 32-40. http://dx.doi.org/10.1016/j.proenv.2012.03.004

12. Spasovski, O. (2013). Heavy and Toxic Metals and Nutrients in Separate Places in the River Bregalnica (Eastern Macedonia). Annual of the university of mining and geology "St.Ivan Rilski” 54 (2): 118-120.

13. Ramani, S., Dragun, Z.,Kapetanović, D., Kostov, V., Jordanova, M., Erk, M., Hajrulai-Musliu, Z.(2014). Surface water characterization of three rivers in the $\mathrm{Pb} / \mathrm{Zn}$ mining region of north-eastern Macedonia. Arch Environ Contam Toxicol. 66 (4): 514-528. http://dx.doi.org/10.1007/s00244-014-0012-z PMid:24626792

14. Strunjak-Perovic, I., Topic Popovic, N., Coz-Rakovac, R., Jadan, M. (2009). Nuclear abnormalities of marine fish erythrocytes. J Fish Biol. 74, 2239-2249.

http://dx.doi.org/10.1111/j.1095-8649.2009.02232.x PMid:20735550
15. Popov, S. I., Stafilov, T., Šajn, R., Tănăselia, C., \& Bačeva, K. (2014). Applying of factor analyses for determination of trace elements distribution in water from river Vardar and its tributaries, Macedonia/ Greece. Sci World J. 2014: 809253. http://dx.doi.org/10.1155/2014/809253

16. de Castilhos Ghisi, N. (2012). Relationship between biomarkers and pesticide exposure in fishes: A review. In: Siundararajan, R.P. (Ed.), Pesticides - advances in chemical and botanical pesticides. InTech Open Access Publisher. http://dx.doi.org/10.5772/48604

17. Shimizu, N., Itoh, N., Utiyama, H., Wahl, M.G. (1998). Selective entrapment of extrachromosomally amplified DNA by nuclear budding and micronucleation during S phase. J Cell Biol. 140 (6): 1307-1320.

http://dx.doi.org/10.1083/jcb.140.6.1307

18. Anbumani, S., Mohankumar, M.N. (2012). Gamma radiation induced micronuclei and erythrocyte cellular abnormalities in the fish Catla catla. Aquat Toxicol. 122-123: 125-132.

http://dx.doi.org/10.1016/j.aquatox.2012.06.001 PMid:22771702

19. Verstraeten, V.L., Peckham, L.A., Olive, M., Capell, B.C., Collins, F.S., Nabel, E.G., Young, S.G., Fong, L.G., Lammerding, J. (2011). Protein farnesylation inhibitors cause donut-shaped cell nuclei attributable to a centrosome separation defect. Proc Natl Acad Sci U S A, 108 (12): 4997-5002. http://dx.doi.org/10.1073/pnas.1019532108 PMid:21383178 PMCid:PMC3064351

20. Nepomuceno, J., Ferrari, I., Spanó, M.A., Centeno, A. (1997). Detection of micronuclei in peripheral erythrocytes of Cyprinus carpio exposed to metallic mercury. Environ Mol Mutagen. 30 (3): 293-297. http://dx.doi.org/10.1002/(SICI)1098-2280(1997)30: $3<293:: A I D-E M 7>3.0 . C O ; 2-\mathrm{M}$

21. Özkan, F., Gündüz, S.G., Berköz, M., Özlüer Hunt, A. (2011). Induction of micronuclei and other nuclear abnormalities inperipheral erythrocytes of Nile tilapia, Oreochromis niloticus, following exposure to sublethal cadmium doses. Turk J Zool. 35 (4): 585-592.

22. Nepomuceno, J.C., Spanó, M.A. (1995). Induction of micronuclei in peripheral erythrocytes of Cyprinus carpio fish by methyl parathion. Rev Int Contam Ambie. 11 (1): 9-12.

23. Udroiu, I. (2006). The micronucleus test in piscine erythrocytes. Aquat Toxicol. 79, 201-204.

http://dx.doi.org/10.1016/j.aquatox.2006.06.013 PMid:16846653

24. Bolognesi, C., Hayashi, M. (2011). Micronucleus assay in aquatic animals. Mutagenesis. 26 (1): 205-213.

http://dx.doi.org/10.1093/mutage/geq073

PMid:21164204 
25. Minissi, S., Ciccotti, E., Rizzoni, M. (1996). Micronucleus test in erythrocytes of Barbus plebejus (Teleostei, Pisces) from two natural environments: a bioassay for the in situ detection of mutagens in freshwater. Mutat Res. 367, 245-251. http://dx.doi.org/10.1016/S0165-1218(96)90084-1

26. Klobučar, G.I.V., Štambuk, A., Pavlica, M., Sertić Perić, M., Kutuzović Hackenberger, B., Hylland, K. (2010). Genotoxicity monitoring of freshwater environments using caged carp (Cyprinus carpio). Ecotoxicology 19, 77-84.

http://dx.doi.org/10.1007/s10646-009-0390-6

PMid:19626438
27. Costa, P.M., Lobo, J., Caeiro. S., Martins, M., Ferreira, A.M., Caetano, M., Vale, C., DelValls, Á., Costa, M.H. (2008). Genotoxic damage in Solea senegalensis exposed to sediments from the Sado Estuary (Portugal): Effects of metallic and organic contaminants. Mutat Res. 654, 29-37.

http://dx.doi.org/10.1016/j.mrgentox.2008.04.007 PMid:18534898

28. European Integrated Pollution Prevention and Control Bureau (EIPPCB) (2003). Reference Document on Best Available Techniques for the Textile Industry. European commission. BREF, 77-85.

Please cite this article as: Ivanova L., Popovska-Percinic F., Slavevska-Stamenkovic V., Jordanova M., Rebok K. Micronuclei and nuclear abnormalities in erythrocytes from barbel Barbus peloponnesius revealing genotoxic pollution of the river Bregalnica. Mac Vet Rev 2016; 39 (2): 159-166. http://dx.doi.org/10.1515/macvetrev-2016-0080 